Case report

\title{
PERINEAL SQUAMOUS CELL CARCINOMA IN A GOAT: A CASE REPORT
}

\author{
G. FARJANIKISH \\ Department of Pathobiology, Faculty of Veterinary Medicine, \\ Lorestan University, Khorram Abad, Iran
}

\section{Summary}

Farjanikish, G., 2017. Perineal squamous cell carcinoma in a goat: A case report. Bulg. J. Vet. Med., 20, No 3, 281-286.

\begin{abstract}
A 4.5-year old female native Iranian goat was presented with history of an irregularly shaped and cauliflower-like non ulcerated mass that affected the perineum which gradually increased in size. The tumour covered the entire orifice of the anus and extended to the dorsal aspect of the vulva. The mass were excised from the base. On cut-section, reddish white fleshy soft surface with $4 \times 3.5 \times 1 \mathrm{~cm}$ dimensions was observed. The enlarging tissue appeared 3 months earlier to presentation as a small neoplastic tissue. The peripheral lymph nodes were normal. There was no evidence of another cutaneous lesion or of metastasis to other organs. Histopathological examination revealed a welldifferentiated squamous cell carcinoma displaying central pearls of keratin and a dense fibrous stroma. The tumour cell was large and had an abundant eosinophilic cytoplasm with slightly enlarged hyperchromatic nuclei. They will often produce large amounts of keratin, resulting in the formation of extracellular keratin pearls. Tumour cells showed hyperchromatism and mitotic figure in some areas. Based on histopathological characteristics the tumour was diagnosed as squamous cell carcinoma.
\end{abstract}

Key words: goat, histopathology, perineum, squamous cell carcinoma

Squamous cell carcinoma (SCC) is a malignant tumour of keratinocytes arising within the epidermis or its appendages that is widely reported in domestic animals (Zabady et al., 2004; Abu-Seida \& Kawkab, 2007). The tumour occurs more frequently in areas deprived of pigmentation, such as eyes, ears, nose, forehead, perineum, vulva and mucocutaneous junctions.

In all species squamous cell carcinomas may occur in young animals, but the incidence increases with age and there does not seem to be any breed predisposition (Goldschmidt \& Hendrick, 2002; Meuten, 2002; Ginn et al., 2007; Rezaie et al., 2012).

SCC is associated to long exposure to ultraviolet (UV) light, unpigmented epidermis and lacking or small number of hair on the affected region (Ramos et al., 2007). Unpigmented mucocutaneous folds showed a higher risk for SCC, mainly in white-haired cattle (Galera \& Martins, 
2001). SCC may also be triggered by chronic irritation of cutaneous wounds leading to tissue metaplasia (Kusewitt \& Rush, 2007). SCC is common in horses, cattle, cats and dogs, relatively uncommon in sheep, and rare in goats and swine.

Squamous cell carcinoma of the perineum is characterised by rapid growth and local invasion of surrounding tissues (Radostits et al., 2007).

The present study describes the morphopathological characteristics of perineal squamous cell carcinoma in a goat.

A 4.5-year old female native Iranian goat was presented with history of an irregularly shaped and cauliflower-like non ulcerated mass that affected the perineum which gradually increased in size. The tumour covered the entire orifice of the anus and extended to the dorsal aspect of the vulva (Fig. 1). The mass were excised from the base. On cut-section, reddish white fleshy soft surface with dimensions $4 \times 3.5 \times 1 \mathrm{~cm}$ was observed. The enlarging tissue appeared 3 months earlier to presentation as a small neoplastic tissue. The peripheral lymph nodes were normal. The- re was no evidence of another cutaneous lesion or of metastasis to other organs.

The appropriate tissues of the tumour mass were fixed in $10 \%$ buffered formalin for histopathological processing. After being embedded in paraffin wax, the blocks were cut into approximately $5 \mu \mathrm{m}$ thick sections and stained with haematoxylin and eosin (H\&E) for microscopic examination.

Histopathological examination revealed many rounded nests of well-differentiated squamous cell carcinoma in which the cells were arranged in concentric circles surrounding a central focus of acellular keratin consistent with keratin pearl (Fig. 2). The tumour cell was large and had an abundant eosinophilic cytoplasm with slightly enlarged hyperchromatic nuclei which often contained multiple prominent nucleoli. They will often produce large amounts of keratin, resulting in the formation of extracellular keratin pearls. Tumour cells showed hyperchromatism and mitotic figure in some areas. A variable inflammatory cell infiltrate, composed mostly of lymphocytes, plasma cells and neutrophils was present (Fig. 3).

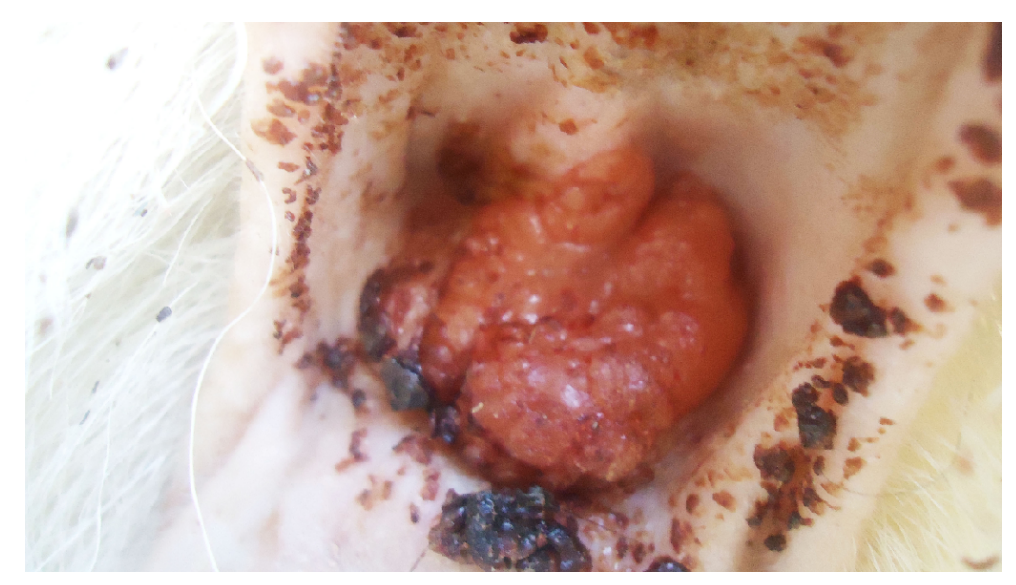

Fig. 1. Perineal SCC in a goat. Irregularly shaped and cauliflower-like non-ulcerated mass affecting the perineum, which covered the entire orifice of the anus. 


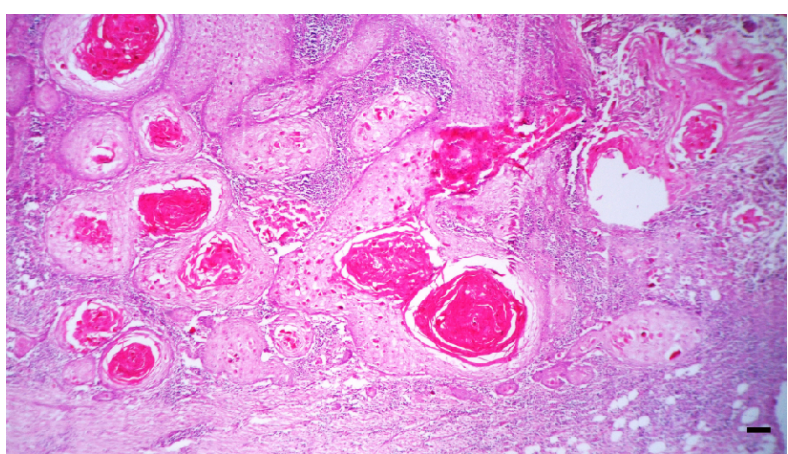

Fig. 2. SCC. Many rounded nests of well-differentiated squamous cell carcinoma show cells arranged in concentric circles surrounding a central focus of acellular keratin consistent with keratin pearl. Note islands of neoplastic epithelial cells, "pearl" formation and moderate mononuclear cell infiltration of stroma (H \& E, Bar= $100 \mu \mathrm{m})$.

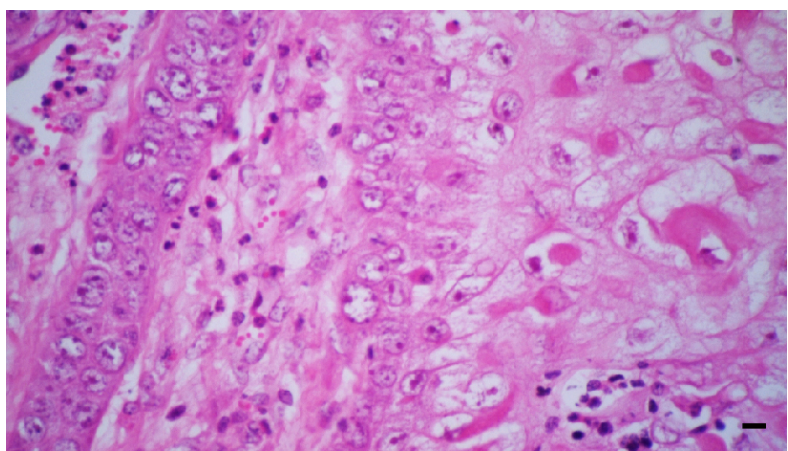

Fig. 3. SCC. The tumour cells are large and have an abundant eosinophilic cytoplasm with slightly enlarged hyperchromatic nuclei which often contain multiple prominent nucleoli. They will often produce large amounts of keratin $(\mathrm{H} \& \mathrm{E}, \mathrm{Bar}=25 \mu \mathrm{m})$.

Based on histological characteristics the tumour was diagnosed as SCC. The follow-up of the case 6 months later showed no evidence of tumour recurrence.

$\mathrm{SCC}$ is a malignant tumour of epidermal cells in which the cells show differentiation to keratinocytes (Goldschmidt \& Hendrick, 2002). Neoplastic epithelial cells on SCC demonstrated variable degrees of squamous differentiation, forming islands, cords or trabeculae in dermis or submucosa associated or not to the proliferation and thickening of the epidermis (Ramos et al., 2007). Histopathological findings in this report were similar to those described by other authors (Stannard \& Pulley, 1978; Mendez et al., 1997; Mara et al., 2005; Fayza et al., 2006; Radostitis et al., 2007; Abu-Seida, 2015).

Histologic grades are based on associated degree of nuclear atypia and keratinisation. The majority of SCCs are well differentiated, with tumour cells containing only slightly enlarged, hyperchromatic nuclei with abundant amounts of cytoplasm. In this case the mass was well differentiated. 
Cutaneous squamous cell carcinoma is a slow growing tumour, but it is locally invasive. It rarely metastasises to regional lymph nodes or with less frequency to other areas of the body. About $12 \%$ of tumours have been observed to metastasise, usually to the regional lymph node, but also to the lung and salivary gland of sheep (Ladds \& Entwistle, 1977). In this case, the peripheral lymph nodes were normal. There was no evidence of another cutaneous lesion or of metastasis to other organs.

Although the etiology of SCC is not clear in all cases, there are several factors that are associated with the development of a SCC, including prolonged exposure to ultraviolet light, lack of pigment within the epidermis at the site of tumour development, and lake of hair or very sparse hair coat at the affected sites (Goldschmidt \& Hendrick, 2002). SCC is common in the horses, cattle, cats and dogs, relatively uncommon in sheep, and rare in goats and swine (Goldschmidt \& Hendrick, 2002).

There are different factors associated with the induction of the neoplasm such as hereditary factors, lack of pigmentation, environmental factors, papillomavirus, genetics, age and dietary habits and other undetermined factors (Anderson \& Badzioch, 1991; Uzal et al., 2000).

The causes of such neoplasms in farm animal are not known but it has been suggested that predisposition to the tumour is probably hereditary (Radostits et al., 2007). In cattle and sheep the etiology has been linked to a number of viral agents, especially bovine papillomavirus (Ford et al., 1982; Vanselow \& Spradbrow, 1983; Rutten et al., 1992). Another contributing environmental factor may have been plant carcinogens like bracken fern (Evans et al., 1982). Further studies on the mecha- nisms underlying SCCs formation are needed.

Animals suffering from SCC may show a good prognosis whenever surgery is performed at the initial stages of the disease (Galera \& Martins, 2001). However, in this report, a bad prognosis was associated to an increase in the size of the mass and cachexia of the patient.

Occurrence of perineal and vulvar SCC has been reported after radical $\mathrm{Mu}$ les' operation and tail docking, which is done to minimise susceptibility to fly-strike, and unproper time of shearing (Swan et al., 1984). Squamous cell carcinoma of the perineum is characterised by rapid growth and local invasion of surrounding tissues. The tumour occasionally metastasises, usually to the regional lymph nodes, which may become enlarged and indurated (Radostits et al., 2007). It is important that the vet will check the local lymph nodes and any sign of spread before treatment is initiated. In this case, the enlarging tissue appeared 3 months earlier to presentation as a small neoplastic tissue. The peripheral lymph nodes were normal and no evidence of another cutaneous lesion or of metastasis to other organs was seen.

Surgical excision is the primary treatment option for most patients with SCC. The ability to completely excise the tumour depends on factors such as the size and location of the tumour. Removal of the tumour can produce good long-term control and prognosis as long as all abnormal tissue is excised. Histopathology conducted by a veterinary pathologist is the best way to determine if the mass has been completely removed. Treatment may also include radiation therapy and chemotherapy (Withrow \& Madewell, 1996).

Early detection and improvement of genetic factors which determine the rate of 
skin pigmentation as well as some management practices may decrease the incidence rate and losses of SCC. In view of the shape, size and posture of the tail of the goat, and lack of pigmentation of the underside of the tail, it is highly likely that solar radiation plays a role in the predisposition to perineal squamous cell carcinomas in this case. Further investigations are needed for determine the epidemiology and geographical distribution of squamous cell carcinomas of goats in this region.

\section{REFERENCES}

Abu-Seida, A. M., 2015. Congenital cutaneous squamous cell carcinoma in a lamb. Asian Journal of Animal Sciences, 9, 80-84.

Abu-Seida, A. M. \& A. A. Kawkab, 2007. External neoplasm in goats. A clinicopathological study of five types. Veterinary Medical Journal (Giza), 55, 33-44.

Anderson, D. E. \& M. Badzioch, 1991. Association between solar radiation and ocular squamous cell carcinoma in cattle. American Journal of Veterinary Research, 52, 784-788.

Evans, W. C., M. C. Patel \& K. Koohy, 1982. Acute Bracken poisoning in homogastric and ruminant animals. Proceedings of the Royal Society Edinburg, 81, 29-64.

Fayza, A. O., O. M. Ahmed \& H. Hamaad, 2006. A note on squamous cell carcinoma in a Saanen goat. The Sudan Journal of Veterinary Research, 21, 93-95.

Ford, J. N., P. A. Jennings, P. B. Spradbrow \& J. Francis, 1982. Evidence for papillomaviruses in ocular lesions in cattle. Research in Veterinary Science, 32, 257-259.

Galera, P. D. \& E. N. Martins, 2001. Superficial keratectomy in ocular squamous cells carcinoma in Simmental cattle: A case report. Arquivo Brasileiro de Medicina Veterinária, 53, 585-588.
Ginn, P. E., J. L. Mansell \& P. M. Rakich, 2007. Skin and appendages. In: Pathology of the Domestic Animals. $5^{\text {th }}$ edn., vol. 1 , eds K. V. F. Jubb, P. C. Kennedy \& N. C. Palmer, W. B. Saunders Co., Philadelphia. pp. 751-753.

Goldschmidt, M. H. \& M. J. Hendrick, 2002. Tumors of the skin and soft tissues. In: Tumors in Domestic Animals, $4^{\text {th }}$ edn, ed D. J. Meuten, Iowa State Press, Ames, pp. 45-118.

Kusewitt, D. F. \& L. J. Rush, 2007. Neoplasia and tumor biology. In: Pathologic Basis of Veterinary Disease, eds M. D. McGavin \& J. F. Zachary, Mosby Elsevier, St. Louis, pp.1263-1315.

Ladds, P. W. \&K. W. Entwistle, 1977. Observations on squamous cell carcinoma of sheep in Queensland, Australia. British Journal of Cancer, 35, 110-114.

Mara, M., G. Diguardo, A. Venuti, G. Marrachella, C. Palmieri, M. De Rugeriis, L. Petrizzi, P. Simeone, C. Rizzo \& D. L. Salda, 2005. Spontaneous ocular squamous cell carcinoma in twin goats: Pathological and biomolecular studies. Journal of Comparative Pathology, 132, 96-100.

Mendez, A., J. Perez, E. Ruiz-Villamor, R. Garcia, M. P. Martin \& E. Mozos, 1997. Clinicopathological study of an outbreak of squamous cell carcinoma in sheep. The Veterinary Record, 141, 597-600.

Meuten, D. J., 2002. Tumors in domestic animals, $4^{\text {th }}$ edn. Iowa State Press, Ames, pp. $52-54$.

Radostits, O. M., C. C. Gay, K. W. Hinchcliff \& P. D. Constable, 2007. Veterinary Medicine: A Textbook of the Diseases of Cattle, Horses, Sheep, Pigs, and Goats, $10^{\text {th }}$ edn, Elsevier Saunders, Edinburgh, pp. 596-597.

Ramos, A. T., D. M. Norte, F. Elias \& C. G. Fernandes, 2007. Squamous cell carcinoma in cattle, sheep and horse. Study of 50 cases in south of Rio Grande do Sul. Brazilian Journal of Veterinary Research and Animal Science, 44, 5-13. 
Rezaie, A., H. Golshahi \& H. Naddaf, 2012. Coincidence of meibomian adenoma and squamous cell carcinoma in the upper eyelid of a sheep: Histopathological and immunohistochemical studies. Iranian Journal of Veterinary Research, 13, 343-346.

Rutten, V. P., W. R. Klein, M. A. De Jong, W. Quint, W. Denotter, E. J. Ruitenberg \& W. J. Melchers, 1992. Search for bovine papilloma virus DNA in bovine ocular squamous cell carcinomas (BOSCC) and BOSCC-derived cell lines. American Journal of Veterinary Research, 53, $1477-$ 1481.

Stannard, A. A. \& L. T. Pulley, 1978. Tumor of the skin and soft tissue. In: Tumors in Domestic Animals, $2^{\text {nd }}$ edn, ed J. E. Moulton, University of California Press, Berkeley, Los Angeles, USA.

Swan, R. A., H. M. Chapman, C. D. Hawkins, J. C. Howell, \& V. T. Spalding, 1984. The epidemiology of squamous cell carcinoma of the perineal region of sheep: Abattoir and flock studies. Australian Veterinary Journal, 61, 146-151.

Uzal, F. A., A. Latorraca, M. Ghoddusi, M. Horn, M. Adamson, W. R. Kelly \& R. Schenkel, 2000. An apparent outbreak of cutaneous papillomatosis in merino sheep in patagonia, Argentina. Veterinary Research Communications, 24, 197-202.

Vanselow, B. A. \& P. B. Spradbrow, 1983. Squamous cell carcinoma of the vulva, hyperkeratosis and papillomaviruses in a ewe. Australian Veterinary Journal, 60, 194-195.

Withrow, S. J. \& D. M. Vail \& E. G. Madewell, 2012. Small Animal Clinical Oncology, $5^{\text {nd }}$ edn, W. B. Saunders Company, Philadelphia, pp. 66.

Zabady, M. K., A. M. Abu-Seida \& K. A. Ahmed, 2004. Clinicopathological study on cutaneous scc and papilloma in sheep. Veterinary Medicine Journal of Giza, 52, 589-600.

Paper received 24.11.2015; accepted for publication 22.01.2016

\section{Correspondence:}

Ghasem Farjanikish, DVM, PhD

Assistant Professor of Veterinary Pathology, Department of Pathobiology,

Faculty of Veterinary Medicine,

Lorestan University,

Khorram Abad, Iran

e-mail: farjanikish.gh@lu.ac.ir;

farjanikish.gh@gmail.com 